\title{
The relationship between uric acid and potassium in normal subjects
}

\author{
ALASTAIR C. KENNEDY, KEITH BODDY, PRISCILLA C. KING, \\ JENNIFER BRENNAN, JOHN A. ANDERSON, AND W. WATSON BUCHANAN
}

From the Centre for Rheumatic Diseases, University Department of Medicine, Royal Infirmary, Glasgow; Scottish Universities Research and Reactor Centre, East Kilbride; and Department of Biomathematics, University of Oxford, Oxford, England

SUMMARY The serum uric acid concentration in normal healthy subjects has been studied in relation to sex, height, weight, lean body mass measured from total body potassium and predicted from the Hume-Weyers formula (1971), total body potassium, plasma potassium and urea, and packed cell volume. The strongest correlation was found with sex, but height, weight, total body potassium, lean body mass (measured and predicted) also correlated significantly with serum uric acid concentration. However, when the sex variable was removed, the other factors lost their significant correlation. Finally, total red blood cell and plasma volumes were predicted (Hume and Goldberg, 1964) and from these an estimate of total plasma uric acid, total plasma potassium, and total red blood cell potassium obtained. Measured total body potassium was found to correlate well with total plasma potassium and total red blood cell potassium independent of sex. Total plasma uric acid correlated well with measured total body potassium when both sexes were considered and when separated into male and female groups the males retained a significant correlation as did the female group.

Serum uric acid concentrations, although subject in the individual to marked fluctuation, are distributed unimodally in large scale population studies (Mikkelsen et al., 1965) and it would seem from twin studies that the major determinant of serum uric acid levels are environmental rather than genetic (Boyle et al., 1967). Several contributing factors, in addition to dietary intake, have been studied; haemoglobin concentration and alcohol consumption (Evans et al., 1968) and psychological traits (Brooks and Mueller, 1966; Kasl et al., 1966) have all been reported to be related to the serum uric acid concentration.

That serum uric acid and body bulk are interrelated has been documented in several races with a variety of geographic, ethnic, and demographic characteristics (Dunn et al., 1963; Prior et al., 1964; Mikkelsen, 1965; Mikkelsen et al., 1965; Acheson and O'Brien, 1966; Burch et al., 1966; O'Brien et al., 1966; Prior and Rose, 1966), although different measures of body bulk have yielded varying

Accepted for publication November 20, 1977

Correspondence to Dr A. C. Kennedy, Centre for Rheumatic Diseases, 35 Baird Street, Glasgow G4 0EH. relationships to serum uric acid concentration (Evans et al., 1968). Evans et al. (1968) found that ponderal index bore a slightly better relationship to serum uric acid than did body weight, but the relative importance of body fat or lean body mass in determining serum uric acid has never been fully explored.

In the present report, serum uric acid has been studied in relation to lean body mass, as represented by direct measurements of total body potassium, similarly the relationship of total body potassium to parameters of blood potassium have been investigated.

\section{Materials and methods}

\section{SUBJECTS}

Fifty-seven normal healthy subjects were studied of whom 30 were female (mean age $27 \cdot 6$ years \pm SEM $1 \cdot 87$, range 18 to 52 years) and 27 were male (mean age $29 \cdot 7$ years $\pm 1 \cdot 90$, range 21 to 57 years). Each subject was receiving a normal solid and fluid diet and none had taken alcohol within the 24 hours preceding the study. Height $(\mathrm{cm})$ and weight $(\mathrm{kg})$ were measured and a sample of serum was separated 
for uric acid estimation (standard colorimetric autoanalyser technique employing phosphotungstic acid).

In 14 normal males and 11 females (mean age $32 \cdot 2$ years \pm SEM $2 \cdot 1$, range 18 to 57 ) a further sample of venous blood was obtained for the determination of plasma urea and potassium concentration, red cell potassium (Boyd, 1970), and packed cell volume.

Total body potassium was measured in each subject using the Merlin mobile shadow-shield whole-body monitor (Boddy, 1967). The subject counting rate in the potassium-40 photopeak $(1 \cdot 36-1 \cdot 56 \mathrm{MeV})$ was expressed as mmol of potassium without the administration of a radioactive isotope, using the procedure described in detail elsewhere (Boddy et al., 1971). The estimated coefficient of variation of this procedure was shown to be $\pm 3.9 \%$ for a subject having $3600 \mathrm{mmol}$ potassium.

By employing the formulae and tables of Hume and Goldberg (1964), it was possible to obtain an estimate of total blood volume, total red blood cell volume, and total plasma volume. Subsequently from these figures an estimate of total plasma uric acid could be obtained for all the control subjects and total plasma potassium and total red cell potassium in the 14 male and 11 female subjects where plasma and red blood cell potassium results were available.

\section{STATISTICAL METHODS}

A step-wise regression and Principal Component Analysis was carried out using two BMD packages on the Oxford 1906 computer of the serum uric acid concentration on sex, total body potassium, and serum urea. Linear regressions of total serum uric acid on total body potassium, of total red cell potassium and total serum potassium on total body potassium were calculated by the method of least squares. The rationale of the step-wise regression is to take the variable most highly correlated with serum uric acid and analyse that regression, then to add the second variable that is most highly coF related after adjustment for the first variable and give the analysis, and then to add the third next highty correlated variable, and so on. The rationale of the Principal Component Analysis is to construct a ne set of variables which are linearly related to the original variables, in this study being 11 in numbe such that the first few variables should contain as much 'information' as possible. For example, in this study the first principal component accounted fơ $67 \%$ of the total variance, but when taken with the second principal component accounted for $79 \%$ of the total variance, etcetera.

\section{Results}

The mean, SEM, and range of each parameter measured in the normal subjects is shown in Table and each is in accord with values obtained in oug own and in other Caucasian studies.

The results of the regression analysis of serum $\vec{p}$ uric acid concentration on height, weight, sex, leaf body mass (measured and predicted), and total bod potassium (measured and predicted) in 57 subject\$ and on the plasma urea, plasma potassium, an intra-red blood cell potassium concentrations 25 subjects on whom it was possible to obtain these measurements are shown in Table 2. It can be that a significant regression exists for serum ür acid on height, weight, sex, lean body mass and total body potassium (both measured and pre dicted) but not for serum uric acid on plasma urea potassium, and intra red blood cell potassiui concentrations.

The step-wise regression and principal compone analysis results indicated that sex was the variable most highly correlated with the serum uric acd concentration and when adjustment was made for this all other factors did not show a significan correlation with the serum uric acid concentratioge Fig. 1 illustrates the plot of measured total bod

Table 1 Clinical and laboratory data expressed as mean $\pm S E M$ in 57 normal subjects

\begin{tabular}{|c|c|c|c|c|c|c|c|c|c|}
\hline & $\begin{array}{l}\text { Height } \\
(\mathrm{cm})\end{array}$ & $\begin{array}{l}\text { Weight } \\
(k g)\end{array}$ & $\begin{array}{l}\text { Measured } \\
\text { TBK }(\mathrm{gm})\end{array}$ & $\begin{array}{l}L B M \text { from } \\
T B K(k g)\end{array}$ & $\begin{array}{l}\text { Uric acid } \\
(\mathrm{mg} / 100 \mathrm{ml})\end{array}$ & $\begin{array}{l}\text { Plasma K } \\
(\mathrm{mmol} / \mathrm{l})\end{array}$ & $\begin{array}{l}\text { Red blood cell } K \\
(\mathrm{mmol} / \mathrm{l})\end{array}$ & $\begin{array}{l}\text { Plasma urea } \\
(\mathrm{mg} / 100 \mathrm{ml})\end{array}$ & $\begin{array}{l}\text { Packed cely } \\
\text { volume }(\%)\end{array}$ \\
\hline Males & $\begin{array}{l}173 \\
\pm \\
1 \cdot 4\end{array}$ & $\begin{array}{l}69 \cdot 8 \\
\pm \\
2.4\end{array}$ & $\begin{array}{l}146 \cdot 1 \\
\pm \quad 3 \cdot 4\end{array}$ & $\begin{array}{l}56.3 \\
\pm \\
0.67\end{array}$ & $\begin{array}{l}6 \cdot 2 \\
\pm \\
0 \cdot 16\end{array}$ & $\begin{array}{l}3 \cdot 95 \\
\pm \\
0 \cdot 15\end{array}$ & $\begin{array}{l}45 \\
\pm \\
0.68\end{array}$ & $\begin{array}{l}32 \cdot 5 \\
\pm \\
1 \cdot 7\end{array}$ & $\begin{array}{l}43.6 \\
\pm \\
0.39\end{array}$ \\
\hline Females & $\begin{array}{l}159.4 \\
\pm 1.0\end{array}$ & $\begin{array}{l}59 \cdot 3 \\
\pm \\
1 \cdot 7\end{array}$ & $\begin{array}{l}96 \cdot 7 \\
\pm \quad 2 \cdot 1\end{array}$ & $\begin{array}{l}43.4 \\
\pm \\
0.5\end{array}$ & $\begin{array}{l}4 \cdot 3 \\
\pm \\
0 \cdot 14\end{array}$ & $\begin{array}{l}3 \cdot 86 \\
\pm \\
0 \cdot 1\end{array}$ & $\begin{array}{l}42 \cdot 2 \\
\pm \\
1 \cdot 1\end{array}$ & $\begin{array}{l}29.4 \\
\pm \\
2.9\end{array}$ & $\begin{array}{ll}40.3 & \stackrel{\varrho}{C} \\
\pm & \frac{c}{D} \\
0.57 & \stackrel{\leftrightarrow}{1}\end{array}$ \\
\hline
\end{tabular}

TBK = total body potassium. LBM = lean body mass. 
Table 2 The separate regressions of serum uric acid concentration on the independent variables measured in the population studied, where $\beta$ is the regression

\begin{tabular}{|c|c|c|c|c|c|}
\hline Independent variable & Slope $(\beta)$ & $S E(\beta)$ & $d f$ & $t$ & $\boldsymbol{P}$ \\
\hline $\begin{array}{l}\text { Height (cm) } \\
\text { Weight (kg) } \\
\text { Sex } \\
\text { Lean body mass (LBM) } \\
\text { Total body potassium (TBK) } \\
\text { Height, weight, age, TBK (predicted) } \\
\text { Height, age, TBK (predicted) } \\
\text { Height, weight, LBM* } \\
\text { Plasma urea concentration } \\
\text { Plasma potassium concentration } \\
\text { Intra-red blood cell potassium (male) } \\
\text { Intra-red blood cell potassium (female) }\end{array}$ & $\begin{array}{l}0.064 \\
0.047 \\
1.898 \\
0.113 \\
0.027 \\
0.029 \\
0.028 \\
0.095 \\
0.087 \\
0.372 \\
0.068 \\
0.002\end{array}$ & $\begin{array}{l}0.016 \\
0.013 \\
0.222 \\
0.018 \\
0.005 \\
0.005 \\
0.005 \\
0.016 \\
0.021 \\
0.446 \\
0.095 \\
0.061\end{array}$ & $\begin{array}{l}57 \\
57 \\
57 \\
57 \\
57 \\
57 \\
57 \\
57 \\
25 \\
25 \\
14 \\
11\end{array}$ & $\begin{array}{l}3 \cdot 93 \\
3 \cdot 77 \\
8 \cdot 50 \\
6 \cdot 34 \\
5 \cdot 93 \\
5 \cdot 78 \\
5 \cdot 22 \\
6 \cdot 06 \\
0 \cdot 97 \\
0 \cdot 83 \\
0 \cdot 72 \\
0 \cdot 04\end{array}$ & $\begin{array}{l}<0.001 \\
<0.001 \\
<0.001 \\
<0.001 \\
<0.001 \\
<0.001 \\
<0.001 \\
<0.001 \\
\text { NS } \\
\text { NS } \\
\text { NS } \\
\text { NS }\end{array}$ \\
\hline
\end{tabular}

*Lean body mass obtained from the height-weight formula of Hume and Weyers (1971).

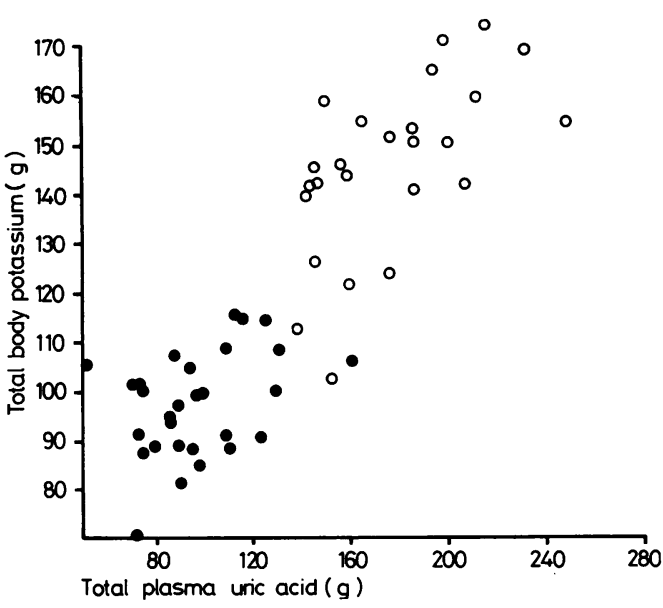

Fig. 1 The correlation between total plasma uric acid and total body potassium in 30 female (๑) and 27 male (o) subjects studied. $r=0.84 ; P<0.001$.

potassium against total plasma uric acid and it can be seen that for the group as a whole there is a significant correlation $(r=0.84, P<0.001)$ and when the group is broken down for sex the correlation persists for males $(r=0.64, P<0.01)$, and for the female group ( $\mathrm{r}=0.45, \mathrm{P}<0.01)$. These results contrast with the lack of correlation between serum uric acid and plasma potassium concentration ( $\mathrm{mmol} / \mathrm{l})$ and also intra-red blood cell potassium concentration (Table 3 ) in the total group or when these are split into male and female groups.

It is of interest that there is a significant correlation between serum uric acid and height and weight when males and females are considered as a single group but when divided by sex, this significance disappears confirming the trend noted in the step-wise regression and principal component analysis. When serum uric acid concentration was expressed as $\mathrm{g}^{-1}$ total body potassium, the mean
Table 3 The correlation coefficient between serum uric acid $(S U A)$ concentration and height and weight in 57 subjects and intra-red blood cell potassium $(R B C K)$ concentration and plasma potassium $(K)$ concentration in 25 subjects in the study

\begin{tabular}{|c|c|c|c|}
\hline \multirow[t]{2}{*}{ Correlates } & \multirow{2}{*}{$\frac{\text { Males }}{(n=27)}$} & \multirow{2}{*}{$\frac{\text { Females }}{(n=30)}$} & \multirow{2}{*}{$\frac{\text { Total }}{(n=57)}$} \\
\hline & & & \\
\hline \multirow[t]{2}{*}{$\begin{array}{l}\text { SUA / } \\
\text { SUA / } \\
\text { weight }\end{array}$} & $\begin{array}{l}r=0.08 \\
P>0.1 \\
r=0.22 \\
P>0.1\end{array}$ & $\begin{array}{l}r=0.15 \\
P>0.1 \\
r=0.2 \\
P>0.1\end{array}$ & $\begin{array}{l}r=0.47 \\
P<0.001 \\
r=0.45 \\
P<0.001\end{array}$ \\
\hline & $(n=14)$ & $(n=11)$ & $(n=25)$ \\
\hline $\begin{array}{l}\text { SUA/ } \\
\text { SUA/ } \\
\text { plasma } K\end{array}$ & $\begin{array}{l}r=0.2 \\
P>0.1 \\
r=0.45 \\
P>0.05\end{array}$ & $\begin{array}{l}r=0.12 \\
P>0.1 \\
r=0.52 \\
P>0.05\end{array}$ & $\begin{array}{l}r=0.34 \\
P>0.05 \\
r=0.13 \\
P>0.1\end{array}$ \\
\hline
\end{tabular}

value in males $(0.043 \pm 0.001$ SEM) was not significantly different $(\mathrm{P}<0.05)$ from that in the female subjects $(0.044 \pm 0.001)$.

When total plasma potassium is correlated with total body potassium (Fig. 2) in the 14 male and 11 female subjects, the correlation coefficient is significant in both males $(r=0.83, P<0.01)$ and females $(r=0.69, P<0.05)$. Similarly, with total body potassium and total red blood cell potassium there is a significant correlation in both male $(r=0.74, P=0.01$ ) groups (Fig. 3).

\section{Discussion}

Many studies have been carried out to ascertain the influence of a multitude of factors on serum levels of uric acid. Reed et al. (1972) showed that serum uric acid levels were positively associated with measures of blood pressure, obesity and serum triglyceride levels in Micronesians which confirmed the previous observation of Burch et al. (1966) of the importance of the geographical factor in serum uric acid. Other studies have also confirmed this association in other areas of the world (Healey and Jones, 


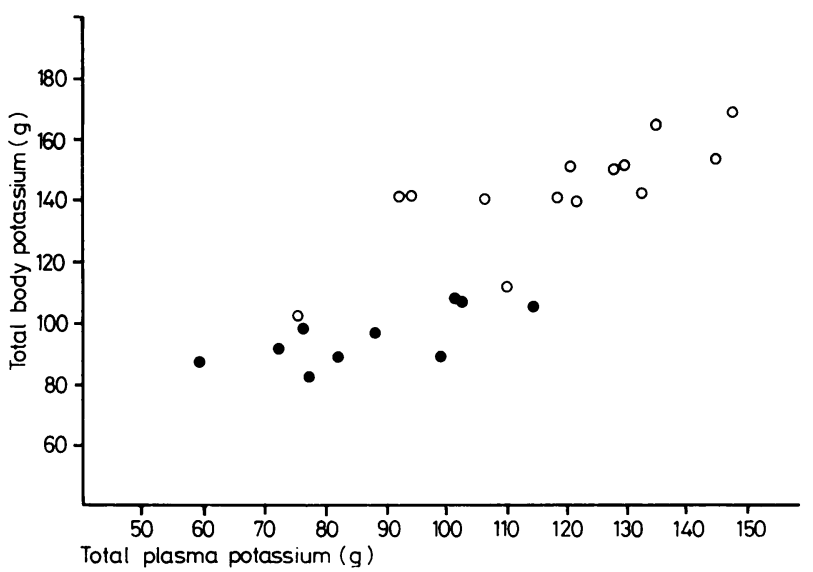

Fig. 2 The correlation between total plasma potassium and total body potassium in 10 female (e) and 14 male (o) subjects studied. $r=0.83 ; P<0.001$ for males. $r=0.69$; $P<0.05$ for females.

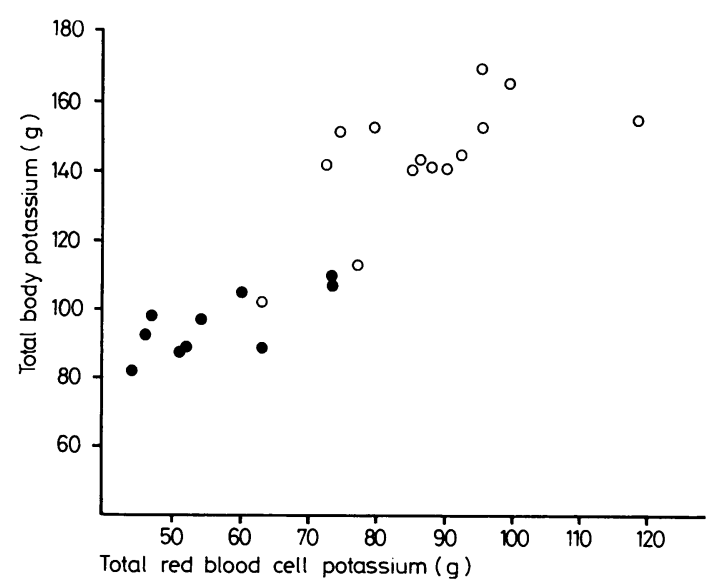

Fig. 3 The correlation between total red blood cell potassium and total body potassium in 10 female $(\bullet)$ and 14 male (o) subjects studied. $r=0 \cdot 71$;

$P<0.01$ for males. $r=0.74 ; P<0.01$ for females.

1971; O'Brien et al., 1966; Zalokar et al., 1972; Laing and Murray, 1973).

In this study we have shown that when the group of subjects are considered in toto, the serum uric acid concentration correlates significantly with height, weight, lean body mass, and total body potassium. Krizek (1966) also demonstrated a linear relationship between serum uric acid concentration and weight in a population of male and female subjects. However, when this group was divided into male and female subgroups, a significant correlation still existed for males $(r=0.6)$ and females $(r=0.42)$ in contrast to the present findings of the loss of significant correlation when the subjects in our study were considered in terms of male and female subgroups. Acheson and O'Brien (1966) in a

study of the relationship of serum uric acid to othew corporeal factors also showed significant cor ${ }_{0}^{\omega}$ relations between serum uric acid and ponderaP index in men and serum uric acid and weight i $\vec{B}$ women. However, it is important to note thaf Krizek's population had an age range of 18-70 yearE్ and his subjects were chosen by reason of obesity and/or because they suffered from one of a varigtie of 'rheumatic diseases' in contrast to our young normal subjects. Similarly the population studid by Acheson and O'Brien (1966) had a much higer mean age (46.4 years) in contrast to our group (males-27.6 years, females-29.7 years), sug gesting that the former study probably contained $\frac{\mathrm{D}}{2}$ considerable number of postmenopausal subjects

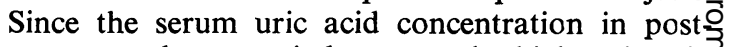
menopausal women is known to be higher than in premenopausal women (Mikkelsen et al., 1965), i is not unlikely that, when contrasting the female populations, where there is a significant differencE in age, varying results are likely to emerge.

The difficulties in interpreting correlating factors. in epidemiological studies of serum uric acid con-8 centrations are highlighted by the study of Acheson and Florey (1969) who investigated 5047 male armyo recruits from Argentine, Brazil, Columbia, and the United States. They found that serum uric acio correlated significantly with weight in the Argentinian and American populations, although the coefficients were small, $r=0 \cdot 189$ and $r=0 \cdot 21$, respectively, $\widetilde{O}$ whereas no correlation was noted for the Columbian and Brazilian populations.

Similarly, Emmerson et al. (1969) in a study of 80 male and 133 female subjects found no correlation between serum uric acid and height, weight, or surface area in the male population. A slight significant correlation was noted between serumo uric acid and weight in the females $(r=0 \cdot 17)$; 
no significance was noted between serum uric acid and height or surface area. This contrasts with other workers who found a significant correlation between ponderal index and serum uric acid in a young male population, although this correlation was low (Kasl et al. 1970).

Nicholls et al. (1973) found that on treating transexual men with oestrogen therapy the serum uric acid concentration fell and urinary uric acid rose suggesting that hormonal differences were responsible for the known age and sex differences in serum uric acid concentration. However, there was no record in this study of weight change or estimation of lean body mass/fat ratio which might be expected to change with oestrogen therapy. These would certainly be of significance since several workers have found correlations between serum uric acid concentration and body weight (Krizek, 1966) body bulk as measured by the ponderal index (Evans et al., 1968) and weight loss (Nicholls and Scott, 1972).

It therefore seemed to us that perhaps the difference of serum uric acid concentration between the two sexes might be due to a variation in lean body mass rather than simply a hormonal effect.

The results (Fig. 1) certainly demonstrate, for the group as a whole, a clear correlation, between total body potassium and total serum uric acid-rather than the simple uric acid concentration and since it has been shown (Boddy et al., 1972) that total body potassium is proportional to lean body mass, this would suggest that the uric acid concentration in the body as a whole is related to lean body mass. However, this cannot alone account for the differences in sex, since, although when separated into male and female subjects, the correlation is still significant the lines of regression for each group diverge. A further piece of evidence against sex per se as the only criterion in determining differences in uric acid concentrations between male and female subjects is the fact that there was no significant differences between either group when serum uric acid was expressed as per grams total body potassium.

These findings contrast with those for potassium in which the mean concentration of potassium in serum was not significantly different between males and females $(P>0.05)$. The mean concentration of potassium in erythrocytes was significantly different, however, in males and females $(P<0 \cdot 05)$. A significant correlation was obtained between the total serum potassium and total body potassium and also between the total erythrocyte potassium and total body potassium.

These latter findings confirm those of Boddy et al. (1976) and in view of the anomalies noted in a study of potassium in patients with rheumatoid arthritis (Nuki et al., 1975) this method would seem to provide a simple basis for assessing further the status of potassium in this and possibly other disease situations.

The results of this study suggest that serum uric acid is a multifactorial determinant and that lean body mass is but one of these factors and cannot by itself account for differences in levels found between the sexes. The study also shows that expression of plasma and red cell potassium in total levels illustrates a correlation between these and total body potassium which is not demonstrable when comparing blood potassium concentration.

We wish to thank Dr R. Hume for guidance and advice given throughout this study and also wish to acknowledge the generous financial support of the Arthritis and Rheumatism Council for Research in Great Britain. The work was supported by a grant from the Medical Research Council and one of us (A.C.K.) was an MRC Clinical Research Fellow.

\section{References}

Acheson, R. M., and O'Brien, W. M. (1966). Dependence of serum uric acid on haemoglobin and other factors in the general population. Lancet, 2, 777-778.

Acheson, R. M., and Florey, C. du V. (1969). Body weight, A B O blood groups and altitude of domicile as determinants of serum uric acid, in military recruits in four countries. Lancet, 2, 391-394.

Boddy, K. (1967). A high sensitivity shadow-field wholebody monitor with scanning bed and tilting chair geometries incorporated in a mobile laboratory. British Journal of Radiology, 40, 631-637.

Boddy, K., Hume, R., White, C., Pack, A., King, P. C., Weyers, E., Rowan, T., and Mills, E. (1976). The relation between potassium in body fluids and total body potassium in healthy and diabetic subjects. Clinical Science and Molecular Medicine, 50, 455-461.

Boddy, K., King, P. C., Hume, R., and Weyers, E. (1972). The relation of total body potassium to height, weight and age in normal adults. Journal of Clinical Pathology, 25, 512-517.

Boddy, K., King, P. C., Tothill, P., and Strong, J. A. (1971). Measurement of total body potassium with a shadowshield whole-body counter; calibration and errors. Physics in Medicine and Biology, 16, 275-282.

Boyd, D. W. (1970). Red blood cell potassium and aldosteronism. Lancet, 1, 594-595.

Boyle, J. A., Greig, W. R., Jasani, M. K., Duncan, A. Diver, M., and Buchanan, W. W. (1967). Relative roles of genetic and environmental factors in the control of serum uric acid levels in normouricaemic subjects. Annals of the Rheumatic Diseases, 26, 234-238.

Brooks, G. W., and Mueller, E. (1966). Serum urate concentrations among university professors relation to drive, achievement and leadership. Journal of the American Medical Association, 195, 415-418.

Burch, T. A., O'Brien, W. M., Need, R., and Kurland, L. T. (1966). Hyperuricaemia and gout in the Mariana Islands. Annals of the Rheumatic Diseases, 25, 114-116. 
Dunn, J. P., Brooks, G. W., Mausner, J., Rodnan, G. P., and Cobb, S. (1963). Social class gradient of serum uric acid levels in males. Journal of the American Medical Association, 185, 431-436.

Emmerson, B. T., Douglas, W., Doherty, R. R., and Feigl, P. (1969). Serum urate concentrations in the Australian aboriginal. Annals of the Rheumatic Diseases, 28, 150-156.

Evans, J. G., Prior, I. A. M., and Harvey, H. P. B. (1968). Relation of serum uric acid to body bulk, haemoglobin, and alcohol intake in two South Pacific Polynesian populations. Annals of the Rheumatic Diseases, 27, 319-325.

Healey, L. A., and Jones, K. W. (1971). Hyperuricaemia in American Samoans. Arthritis and Rheumatism, 14, 283-285.

Hume, R., and Goldberg, A. (1964). Actual and predictednormal red-cell and plasma volumes in primary and secondary polycythaemia. Clinical Science, 26, 499-508.

Hume, R., and Weyers, E. (1971). Relationship between total body water and surface area in normal and obese subjects. Journal of Clinical Pathology, 24, 234-238.

Kasl, S. V., Brooks, G. W., and Cobb, S. (1966). Serum urate concentrations in male high-school students. Journal of the American Medical Association, 198, 713-716.

Kasl, S. V., Brooks, G. W., and Rodgers, W. L. (1970). Serum uric acid and cholesterol in achievement behaviour and motivation. I. the relationship to ability grades, test performance, and motivation. Journal of the American Medical Association, 213, 1158-1164.

Krizek, V. (1966). Serum uric acid in relation to body weight. Annals of the Rheumatic Diseases, 25, 456-458.

Laing, J. K., and Murray, J. T. (1973). Serum uric acid levels in New Zealanders. New Zealand Medical Journal, 78, 65-67.
Mikkelsen, W. M. (1965). The possible association of hyper-市 uricaemia and/or gout with diabetes mellitus. Arthritis and Rheumatism, 8, 853-864.

Mikkelsen, W. M., Dodge, H. J., and Valkenburg, H. (1965). The distribution of serum uric acid values in a population. unselected as to gout or hyperuricaemia. American Journal $\underset{\vec{\rho}}{\text { of Medicine, 39, 242-251. }}$
a

Nicholls, A., and Scott, J. T. (1972). Effect of weight-loss ono plasma and urinary levels of uric acid. Lancet, 2, 1223-1224.তे

Nicholls, A., Snaith, M. L., and Scott, J. T. (1973). Effect of oestrogen therapy on plasma and urinary levels of uric acid. British Medical Journal, 1, 449-451.

Nuki, G., Boddy, K., Kennedy, A. C., King, P., Duncan, A. N., and Buchanan, W. W. (1975). Potassium metabolism in patients with rheumatoid arthritis. Effects of $\overrightarrow{0}$ treatment with depot tetracosactrin spironolactone and oral supplements of potassium chloride. Annals of the $\vec{\omega}$ Rheumatic Diseases, 34, 506-514.

O'Brien, W. M., Burch, T. A., and Bunim, J. J. (1966). Genetics of hyperuricaemia in Blackfeet and Pima Indians Annals of the Rheumatic Diseases, 25, 117-119.

Prior, I. A. M., and Rose, B. S. (1966). Uric acid, gout and ${ }^{-}$ public health in the South Pacific. New Zealand Medical Journal, 65, 295-300.

Prior, I. A. M., Rose, B. S., and Davidson, F. (1964) $\omega$ Metabolic maladies in New Zealand Maoris. British Medical Journal, 1, 1065-1069.

Reed, D., Labarthe, D., and Stallones, R. (1972). Epi-D demiologic studies of serum uric acid levels amongc Micronesians. Arthritis and Rheumatism, 15, 381-390.

Zalokar, J., Lellouch, J., Claude, J. R., and Kuntz, D. (1972). Serum uric acid in 23,923 men and gout in a subsample of $\vec{\varphi}$ 4,257 men in France. Journal of the Chronic Diseases, $\mathbb{5}, \infty$ 305-312. 